\title{
Glucocorticoids Shape Macrophage Phenotype for Tissue Repair
}

\author{
Thibaut Desgeorges ${ }^{1 \dagger}$, Giorgio Caratti ${ }^{2 \dagger}$, Rémi Mounier ${ }^{1}$, Jan Tuckermann ${ }^{2}$ and \\ Bénédicte Chazaud ${ }^{1 *}$ \\ ${ }^{1}$ Institut NeuroMyoGène, Université Claude Bernard Lyon 1, Univ Lyon, CNRS UMR 5310, INSERM U1217, Lyon, France, \\ ${ }^{2}$ Institute of Comparative Molecular Endocrinology, University of UIm, UIm, Germany
}

\section{OPEN ACCESS}

Edited by:

Claude Libert,

Flanders Institute for Biotechnology,

Belgium

Reviewed by:

Inez Rogatsky,

Hospital for Special Surgery,

United States

Heinz Baumann,

University at Buffalo, United States

*Correspondence:

Bénédicte Chazaud benedicte.chazaud@inserm.fr

†These authors have contributed equally to this work

Specialty section: This article was submitted to Inflammation,

a section of the journal

Frontiers in Immunology

Received: 16 April 2019

Accepted: 25 June 2019

Published: 09 July 2019

Citation:

Desgeorges T, Caratti G, Mounier R, Tuckermann J and Chazaud B (2019) Glucocorticoids Shape Macrophage Phenotype for Tissue Repair.

Front. Immunol. 10:1591.

doi: 10.3389/fimmu.2019.01591
Inflammation is a complex process which is highly conserved among species. Inflammation occurs in response to injury, infection, and cancer, as an allostatic mechanism to return the tissue and to return the organism back to health and homeostasis. Excessive, or chronic inflammation is associated with numerous diseases, and thus strategies to combat run-away inflammation is required. Anti-inflammatory drugs were therefore developed to switch inflammation off. However, the inflammatory response may be beneficial for the organism, in particular in the case of sterile tissue injury. The inflammatory response can be divided into several parts. The first step is the mounting of the inflammatory reaction itself, characterized by the presence of pro-inflammatory cytokines, and the infiltration of immune cells into the injured area. The second step is the resolution phase, where immune cells move toward an anti-inflammatory phenotype and decrease the secretion of pro-inflammatory cytokines. The last stage of inflammation is the regeneration process, where the tissue is rebuilt. Innate immune cells are major actors in the inflammatory response, of which, macrophages play an important role. Macrophages are highly sensitive to a large number of environmental stimuli, and can adapt their phenotype and function on demand. This change in phenotype in response to the environment allow macrophages to be involved in all steps of inflammation, from the first mounting of the pro-inflammatory response to the post-damage tissue repair.

Keywords: glucocorticoids, macrophages, inflammation, tissue repair, phagocytosis glucocorticoid receptor

Macrophages therefore, appear to be an ideal target of anti-inflammatory drugs due to their central role in inflammation. Glucocorticoids (GCs) are highly potent anti-inflammatory drugs, commonly used around the world. GCs have been used for decades to treat a variety of inflammatory diseases such as rheumatoid arthritis, contact allergy, or pulmonary diseases. Since the first GC therapies during the 1950s, various synthetic GCs have been developed to optimize their action, and new molecules are still under development to modulate therapeutic effects vs. the adverse effects of these drugs. Surprisingly, given the importance of macrophages in the inflammatory response, the direct effects of GCs on macrophages are less well-documented. The present review aims at summarizing the knowledge on macrophage functions during the post-injury inflammatory response, with a focus on sterile inflammation and tissue repair, discussing how GC signaling pathways operate in macrophages, and finally on the specific action of GCs on macrophages. 


\section{MACROPHAGES AND TISSUE REPAIR-EXAMPLE OF SKELETAL MUSCLE REGENERATION}

\section{Similar Macrophage Subtypes Are Found in Various Tissues During Repair}

Macrophages belong to the innate immune system, however their role is far more than protecting against pathogens. In the late nineteenth century, Metchnikoff originally described and named these cells as "macro" (big) "phage" (eaters) due to their phagocytotic activity. In the following 100 years, scientists discovered that macrophages are not only phagocytic cells. Different macrophage subtypes were described, first in in vitro experiments, based on the main cytokinic activation of lymphocytes, allowing macrophages to be divided into different categories. "Classically activated" macrophages are induced by stimulation with the Th1 cytokine IFN $\gamma$ and "alternatively activated" macrophages, involved in anti-inflammatory processes were observed when using the Th2 cytokine IL-4 (1). These two activation states were also called M1 (or pro-inflammatory macrophages) and M2 (or anti-inflammatory macrophages), respectively. However, this simplistic view of two potential statuses was quickly expanded on. Macrophages can adopt a very large panel of phenotypes depending on the inflammatory cues they encounter, even in vitro (2-4). In vivo, the situation is more complex. The terms M1 and M2, although widely used, are not appropriate to describe specific and dynamic inflammatory status that occurs in the inflammatory milieu of a living organism $(5,6)$. The Ly6C (Lymphocyte antigen 6 complex, a membrane protein expressed by monocytes, and macrophages) and CX3CR1 (chemokine (C-X3-C motif) receptor 1 , another transmembrane protein involved in the adhesion and migration of leukocytes) antigens have been widely used to classify pro-inflammatory and anti-inflammatory macrophages in the context of postinjury inflammatory response (7). During sterile inflammation, pro-inflammatory $\mathrm{Ly} 6 \mathrm{C}^{\text {pos }} \mathrm{CX} 3 \mathrm{CR} 1^{\text {neg }}\left(\mathrm{CCR} 2{ }^{\text {pos }} \mathrm{F} 4 / 80^{\text {low }}\right)$ cells infiltrate the injured tissue. After a rather undefined set of signaling events, a phenotypic switch occurs whereby macrophages lose Ly6C and CCR2 and gain CX3CR1 and F4/80 (forming $\mathrm{Ly} 6 \mathrm{C}^{\text {neg }} \mathrm{CX} 3 \mathrm{CR} 1^{\text {pos }} \mathrm{CCR} 2^{\text {low/neg }} \mathrm{F} 4 / 80^{\text {high }}$ cells) corresponding to their anti-inflammatory status (8). This sequence of events from the infiltration of pro-inflammatory macrophages to the phenotypic switch toward anti-inflammatory activity appears to be universal. These events have been described after injury in heart (9), central nervous system $(10,11)$, liver (12), kidney $(13,14)$, and skeletal muscle (15-18).

\section{Skeletal Muscle Regeneration}

The core cell type within skeletal muscle is the myofiber-a multinucleated cell formed by fusion of precursor cells (19). Skeletal muscle has a high regenerative capacity, after injury, muscle regenerates ad integrum, where the old damaged cells are replaced by proliferation and differentiation of satellite cells, which are the muscle resident stem cells (MuSCs). Skeletal muscle regeneration, therefore, is an ideal paradigm to study the biological events involved in tissue repair/regeneration, helped by highly reproducible experimental models in mouse (20) Satellite cells are localized under the basal lamina surrounding each myofiber, in a quiescent state. After an injury, damaged myofibers undergo necrosis which triggers alteration of the satellite cell niche, in turn leading to their activation (19). Activated MuSCs proliferate, in order to produce a critical pool of cells necessary to repair muscle, after which MuSCs differentiate into myocytes, that eventually fuse to form new myofibers. While myogenesis takes place, multiple other biological processes occur simultaneously during muscle regeneration. Angiogenesis is required for efficient muscle regeneration. Endothelial cells and MuSCs communicate through secreted factors to mutually promote myogenesis and angiogenesis (21). Fibro-Adipogenic Precursors (FAPs) control the extracellular matrix remodeling during muscle regeneration, depending on the number and differentiation status of the FAPs (22). Thus, muscle regeneration is a complex process where multiple cell types interact and coordinate to reconstruct the tissue (Figure 1).

Each step of muscle regeneration is linked to the inflammatory response, which is mainly mediated by macrophages. Macrophages modulate myogenesis through MuSCs (17), as well as angiogenesis (21), and matrix remodeling (22) that occur concomitantly. Macrophages represent more than $75 \%$ of the leukocytes present in a regenerating muscle; however other immune cells are present in lower numbers (16) and are more prominent during the early steps of muscle regeneration. Neutrophils are transiently present during the very first days after injury, but their contribution to muscle regeneration has not been deciphered yet and may depend on the extent of the injury (23). Eosinophils participate in muscle regeneration through the secretion of IL-4 that activates FAP proliferation (24). Tregs secrete the growth factor amphiregulin that stimulates MuSC expansion and differentiation (25). Therefore, macrophages are major actors in the regulation of skeletal muscle regeneration through the establishment of various interactions with several cell types. While the above-mentioned studies clearly show how macrophagic populations impact on other cell types, the effect of those cells on macrophage phenotype and function has not been evidenced yet.

\section{The Inflammatory Phase During Muscle Regeneration}

Tissue injury triggers the release of chemoattractants into the bloodstream that recruit circulating leukocytes. Monocyte entry into the injured muscle is regulated through the CCL2 (MCP1)/CCR2 axis. In mouse models of CCR2 or CCL2 depletion, muscle regeneration is severely hindered (26, $27)$. Indeed, only circulating $\mathrm{Ly} 6 \mathrm{C}^{\mathrm{pos}} \mathrm{CCR} 2{ }^{\text {pos }}$ monocytes are recruited into the injured muscle $(6,15,18)$. In the nur $77 \mathrm{KO}$ mouse model where CCR2 ${ }^{\text {neg }}$ Ly6 ${ }^{\text {neg }}$ monocytes are absent from the circulation, muscle regeneration occurs normally, indicating that circulating $\mathrm{CCR} 2^{\text {neg }} \mathrm{Ly} 6 \mathrm{C}^{\text {neg }}$ monocytes are not recruited into the injured muscle $(15,18)$. Once in the tissue, macrophages clear debris from apoptotic and necrotic cells through efferocytosis. They also potentiate the survival and growth of MuSCs by establishing direct cell-cell contacts $(28,29)$. 

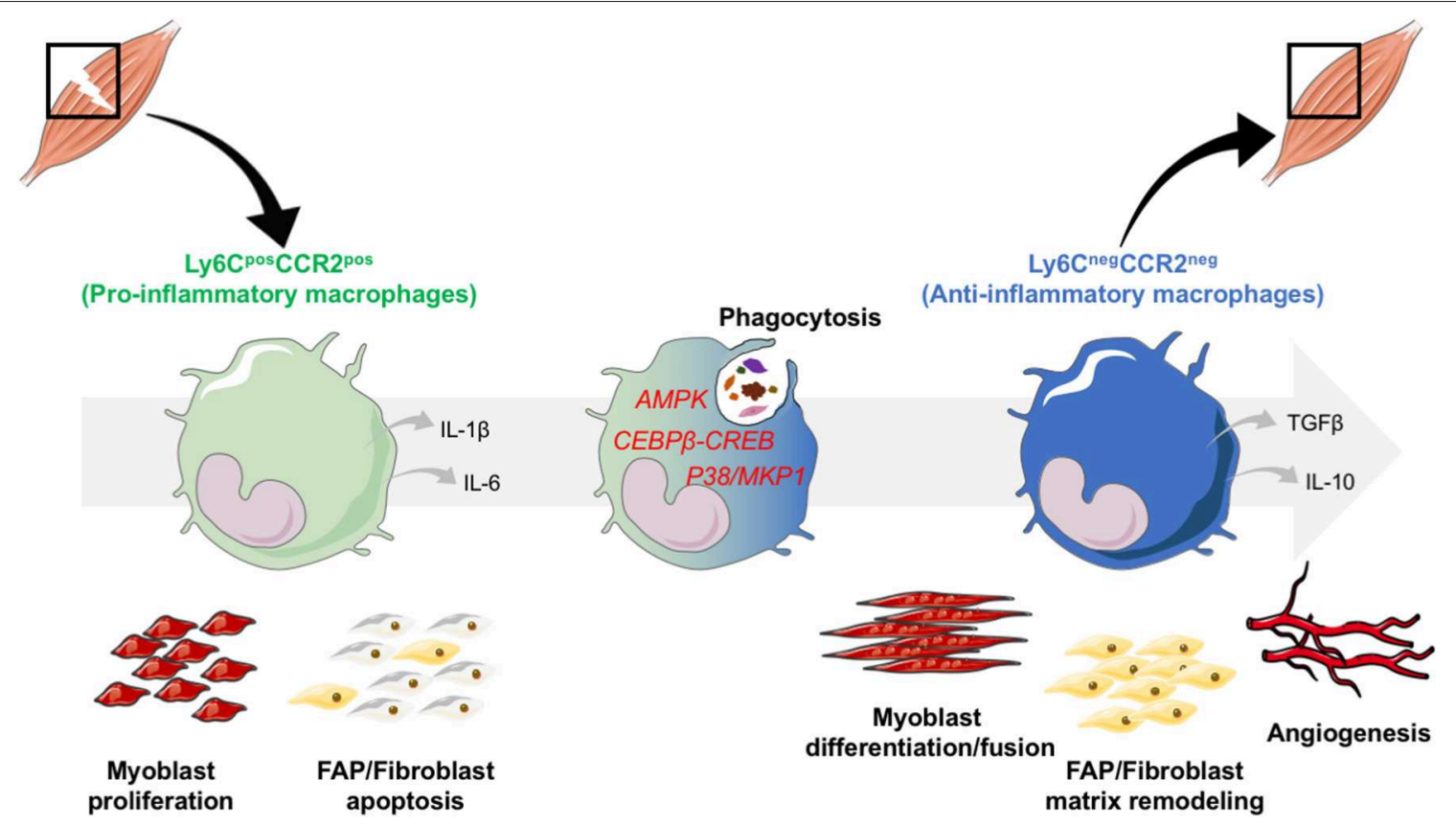

FIGURE 1 | Phenotype switch of macrophages regulates skeletal muscle regeneration. After an injury, monocytes are recruited from the bloodstream, and infiltrate the damaged area. In the tissue, monocytes acquire a damaged associated pro-inflammatory phenotype. They secrete inflammatory cytokines such as IL-1 $\beta$ and IL- 6 and exert specific functions: they stimulate the proliferation of the myogenic precursors (myoblasts) and trigger fibroblast apoptosis to avoid excessive matrix deposition. Upon phagocytosis of cell debris that triggers the activation of AMPK, CEBP $\beta$-CREB axis and P38/MKP1 pathways, pro-inflammatory macrophages switch their phenotype toward an anti-inflammatory restorative phenotype. Through the secretion of a variety of factors, among which anti-inflammatory cytokines IL-10 and TGF $\beta$, anti-inflammatory macrophages are involved in tissue repair and regeneration through the stimulation of myoblast differentiation and fusion, of FAP/fibroblasts for matrix remodeling and of angiogenesis.

Moreover, pro-inflammatory macrophages secrete factors such as IL-6, IL-1 $\beta$, or VEGF that stimulate MuSC proliferation $(15,17)$. Finally, pro-inflammatory macrophages control FAP apoptosis, preventing excess matrix deposition by fibroblastic cells $(22,30)$.

\section{Macrophage Phagocytosis and the Resolution of Inflammation}

At the time of resolution of inflammation, pro-inflammatory macrophages shift toward an anti-inflammatory phenotype (Figure 1). Signaling pathways involved in this switch are beginning to be documented in the literature. Currently, 3 main intracellular pathways have been described: AMPK, p38/MKP1, CREB-C/EBP $\beta$ (see below section "Time and space orchestration of the inflammatory response"). While the activation of these pathways is required, the activating upstream cues are still unknown. However, one likely candidate is the phagocytotic pathway that has been shown to be essential for the acquisition of an anti-inflammatory phenotype. Efferocytosis, that is the ingestion of apoptotic cells by macrophages, results in a reduction of pro-inflammatory markers, and an increase in the expression of anti-inflammatory markers, suggesting that the death signals of apoptotic cells may contribute to the generation of an anti-inflammatory phenotype (31-33). Anti-inflammatory macrophages act on several cell types in regenerating skeletal muscle, inducing both differentiation, and fusion of MuSCs as well as growth of the newly regenerated myofibers (15-17). Anti-inflammatory macrophages promote extracellular matrix remodeling by inducing fibroblast survival and collagen production through the secretion of TGF- $\beta$ (30). In vitro experimentation has shown that antiinflammatory macrophages stimulate endothelial cell sprouting and differentiation, inducing vessel formation concomitantly to myogenesis, through the secretion of specific effectors, such as the cytokine Oncostatin M (21). Accordingly, CCR2 KO mice exhibit defect of vascularization in the regenerating muscle, as macrophages are not efficiently recruited to the site of injury (34). Thus, anti-inflammatory macrophages are a key component of the regeneration phase. They act on multiple cell types within the muscle, promoting growth of newly formed muscle cells, remodeling of extracellular matrix and revascularization all simultaneously, allowing the full, and importantly functional, recovery of the muscle tissue.

\section{Time and Space Orchestration of the Inflammatory Response}

The inflammatory response needs to be tightly orchestrated to be efficient, and the regulation of macrophage activity is no exception. Resolution of inflammation is a key step in skeletal muscle regeneration, that must occur timely. Indeed, when the pro-inflammatory phase is blunted by the inhibition of the expression of the proinflammatory cytokine IFN $\gamma$ (35) or reduced by the 
early administration of anti-inflammatory cytokine IL10 (36), muscle regeneration is impaired, resulting in the formation of smaller myofibers. Similarly, blunting the inflammatory phase by administrating anti-inflammatory drugs or icing the early injured muscle to prevent the entry of monocytes is detrimental for muscle regeneration [reviewed in (37)].

AMP-activated protein kinase (AMPK), a key metabolic regulator is also important for the generation of antiinflammatory macrophages (16). Similarly, the p38/MKP1 pathway (MAP kinase pathway) modulates the phenotype of macrophages. Inhibition of the phosphatase MKP1 allows for an early activation of AKT, leading to a too early acquisition of the anti-inflammatory status in macrophages, resulting in to an impairment of muscle regeneration (36). Finally, blocking the CREB-C/EBP $\beta$ cascade prevents the acquisition of the anti-inflammatory phenotype of macrophages, that also impairs muscle regeneration (38). Given the importance of the process of the resolution of inflammation for tissue homeostasis, it is likely that other pathways are also involved in the switch of the inflammatory status of macrophages.

\section{GLUCOCORTICOIDS: A GENERAL OVERVIEW}

\section{Origins of GCs}

The hypothalamic-pituitary-adrenal axis is critical for the regulation of a variety of biological processes: stress, feeding, circadian rhythm, growth, and reproduction. GC production is regulated, via multiple hormonal inputs at all levels of the axis [reviewed in $(39,40)]$. The hypothalamus secretes corticotropin releasing hormone $(\mathrm{CRH})$, the first step in the regulation of GC secretion. $\mathrm{CRH}$ is controlled through input of the nervous system, such as exposure to stress, circulating hormones like progesterone and adrenaline, but also by GCs. $\mathrm{CRH}$ acts on the pituitary gland to induce the secretion of the Adreno Cortico Tropic Hormone (ACTH) into the bloodstream. ACTH binds to its receptor on cells of the adrenal cortex to regulate the secretion of a variety of hormones, especially the GC cortisol (in humans), and corticosterone (in mouse). The HPA axis, and therefore GC production is also under control of the inflammatory response. Using computational modeling and comparison to clinical data, it was demonstrated that after an inflammatory trigger, ACTH and cortisol rise within minutes to hours, slightly after cytokine release. However, this is not maintained for long, and returns to baseline after $10 \mathrm{~h}$ (41). The homeostatic release of GCs after an inflammatory challenge plays an important protective role, which without (e.g., through a disrupted HPA axis) results in relatively mild inflammation becoming deadly [reviewed in (42)]. Investigation into the potential medical use of GCs started in the 1930s, where Philip Hench, Edward Kendall, and Tadeusz Reichstein showed the incredible therapeutic potential of these molecules as anti-inflammatory drugs, and later received the Nobel prize for their work in 1950. From that point, GC therapies spread all around the world and are still used today to counter inflammation.

\section{The GC Receptor}

GCs act through the Glucocorticoid Receptor (GR), a member of the nuclear receptor superfamily, and first cloned in 1985 (43). The gene encoding GR is located on the locus $5 \mathrm{q} 31.3$ in the human genome comprised of 9 exons (43). GR expression gives rise to the expression of 2 major isoforms: GR $\alpha$ (777 amino acids) and GR $\beta$ (742 amino acids), along with other less well-expressed (and less well-studied) isoforms (43). GR $\alpha$ is the active isoform that binds GCs and that regulates target gene expression. GR $\beta$ isoform is a regulator of the $\alpha$ isoform, acting as a dominant negative $(44,45)$. A third isoform of the receptor, GR $\gamma$ has also been characterized. This isoform only differs from GR $\alpha$ by one arginine in the DNA Binding Domain (DBD) that alters the capacity for the isoform to regulate gene expression, giving GR $\gamma$ its own transcriptomic profile (46). This altered profile may play a role in GC resistant leukemia (47), however its action during inflammation has not yet been extensively studied.

The 3D structure of GR is comprised of several domains: the $\mathrm{N}$-terminal domain, the $\mathrm{DBD}$, the hinge region, the Ligand Binding Domain (LBD) and the C-terminal domain (48-50).

GR, like other nuclear receptors is a ligand regulated transcription factor, which regulates gene expression by binding either directly, or indirectly to the genome [review in (51)]:

Activation: after ligand binding in the cytoplasm, GR translocates to the nucleus, and directly binds specific palindromic regions on DNA called Glucocorticoid Response Elements (GREs). GREs are present in the regulatory regions, such as the promoters, enhancers, and even within the exons or introns of target genes (such as Gilz and Dusp1) and binding of GR dimers induces the transcription of these genes (positive GRE) (51). Transactivation can also occur by a tethering mechanism, whereby GR associates with other transcription factors that positively drive gene expression. Transcription can also be induced by monomeric GR that binds DNA to a half-site motif (52).

- Repression: as with activation, nuclear GR can bind DNA and represses the transcription of genes. GR can directly act as a monomer in association with other transcription factors such as NFkB (53) or AP-1 (54) to transrepress gene expression by a tethering mechanism (51). GR monomer sequestrates transcription factors to prevent their binding to promoters and so to prevent transcription. Moreover, GR cis-repress genes by directly binding so called negative GREs or by directly binding the NFKB or AP-1 response elements (55). More mechanisms are currently emerging driven by genome wide studies that are reviewed in detail elsewhere in this Research Topic (Escoter-Torres et al., Submitted).

Thus, GR is a transcription factor that regulates gene expression through several pathways [reviewed in $(45,49,56,57)$ ] and in a tissue dependent manner (58). Non-genomic effects of GCs, that is $\mathrm{GC}$ regulated actions that are independent from the regulation 
of gene expression, have been described in several tissues and that were very recently reviewed in Panettieri et al. (59).

\section{Adverse Effects of GCs}

During the 1960s, it became clear that clinical use of GCs causes severe metabolic side effects. In 1970, David and colleagues reviewed 20 years of GC utilization (60). They discussed side effects that were observed in almost all tissues of the body. In 1970, it was already known that long exposure to GCs was responsible for several metabolic disturbances, but more recent studies have expanded on this, dramatically enhancing our knowledge about GC effects on metabolic organs. Chronic GC use results in the development of type 2 diabetes (due to increased gluconeogenesis, hepatosteatosis, decreased insulin sensitivity, and decreased glucose consumption) (61-63), skin $(64,65)$, and muscle atrophy (66), and bone mass reduction (both due to induction of catabolism and/or reduction of anabolism) (67). Moreover, free fatty acids are increased in the bloodstream and in clinical cases of GC excess-for example Cushing's Disease, this results in increased adipose tissue mass, but usually localized to the face and truck, resulting in a "Moon-Face" and "Buffalo Hump" $(68,69)$. Although literature documenting GC side effects is very abundant, the molecular mechanisms involved have not been completely elucidated, in part due to the complexity of the tissue specific effects of GCs.

Anti-inflammatory effects of GCs were historically associated with the monomeric form of GR, mainly due to the evidence that GR can bind and inhibit, and thus transrepresses the inflammatory transcription factor $\mathrm{NF} \kappa \mathrm{B}$, downregulating the expression of pro-inflammatory cytokines $(39,70)$. The metabolic actions of GR were ascribed to the dimer, suggesting that drugs specific to monomeric, over dimeric GR would exhibit all beneficial anti-inflammatory effects without having negative side effects. A mouse model, in which GR dimerization is impaired $\left(\mathrm{GR}^{\mathrm{dim}}\right)$, has allowed several laboratories to show that GR dimerization is also required for the anti-inflammatory properties of GCs in several contexts, such as rheumatoid arthritis $(71,72)$, septic shock $(73,74)$, or inflammatory bowel disease (75). Interestingly however, the metabolic side effects of GCs are enhanced in the GR ${ }^{\mathrm{dim}}$ mice. The loss of dimerization can drive increased insulin resistance and obesity, suggesting that the classical view of monomeric GR only being associated with the anti-inflammatory actions is not entirely correct (76). Therefore, both inflammatory and metabolic regulation by GCs may be driven by both the dimer and the monomer, depending on the cell type, the tissue, and the pathology considered.

\section{GLUCOCORTICOIDS, MACROPHAGES, AND TISSUE REPAIR}

First investigations into the action of GCs on macrophages during tissue repair started a few decades ago. One of the side-effects of chronic GC exposure is the loss of bone mass (osteopenia/osteoporosis). Bone resorption, that is, the digestion of existing bone, is more efficient when highly specialized macrophages involved in bone remodeling, osteoclasts, are in direct contact with the bone. Resident tissue osteoclasts are derived from myeloid progenitor cells during development, however they are maintained throughout life by circulating blood monocytes fusing to existing osteoclasts in the bone (77). Osteoclasts treated with cortisol are more adherent to bone, more sensitive to RANKL, and release more calcium useable for bone resorption, enhancing the bone resorption process (78-80). GCs also increase osteoclastogenesis by driving the production of RANKL, the necessary factor for osteoclast differentiation, and downregulating osteoprotegerin, the decoy receptor for RANKL $(81,82)$. It was possible to prevent GC-induced osteoporosis by treating mice with a RANKL neutralizing antibody, further demonstrating that the effects of GCs on osteoclasts contribute to the bone loss that occurs during GC treatment (83). GCs can also have direct effects on osteoclasts. Using either mice deficient for GR in osteoclasts or 11BHSD2 overexpressing mice (where the GC inactivating enzyme is over-expressed in osteoclasts), it was confirmed that GCs act directly on osteoclasts to modulate bone density, in part by increasing the life span of osteoclasts $(84,85)$. Interestingly, chronic treatment with GCs decreases osteoclast life-span, suggesting a temporal effect $(67,86)$.

A mouse model based on the cre/loxP system was designed to specifically deplete GR in the myeloid lineage where the cre recombinase gene is located at the Lysozyme $\mathrm{M}$ locus. These so-called $\mathrm{LysM}^{\mathrm{cre}} ; \mathrm{GR}^{\mathrm{fl} / \mathrm{fl}}$ mice, delete GR in monocytes, macrophages and neutrophils. In a mouse model of contact hypersensitivity, the anti-inflammatory effects of GCs were shown to be mediated through GR in macrophages, rather than other tissues. Treatment of $\mathrm{LysM}^{\mathrm{cre}} ; \mathrm{GR}^{\mathrm{f} / \mathrm{fl}}$ mice with GCs failed to repress the cytokines IL1- $\beta$, MCP1, MIP2, and IP10. In addition, $\mathrm{GR}^{\mathrm{dim}}$ mice are also insensitive to GCs, indicating that GR dimerization, likely in macrophages, is required in this context (87). In a model of myocardial infarction, $\mathrm{LysM}^{\mathrm{cre}} ; \mathrm{GR}^{\mathrm{fl} / \mathrm{fl}}$ mice die earlier after infarction than wild-type animals with full expression of macrophage GR, probably due to the persistence of Ly6C $\mathrm{C}^{\text {pos }}$ macrophages into the infarcted area, leading to a dysregulation of the resolution of inflammation and a defects in wound healing. This results in alteration of angiogenesis, abnormal production of TGF $\beta$, decreased production of IL- $1 \alpha$ and finally deregulation of myofibroblast differentiation leading to scar formation (88). Moreover, in a mouse model of inflammatory bowel disease, macrophages from $\mathrm{LysM}^{\mathrm{cre}} ; \mathrm{GR}^{\mathrm{fl} / \mathrm{fl}}$ animals show a defect in the acquisition of the anti-inflammatory status. After 10 days, IL-1 $\beta$, and IL-6 expression is not repressed and expression of anti-inflammatory genes (CD163, CD206, and IL-10) is not induced, leading to a defect in tissue repair (89). Local availability of GCs also plays an important role in inflammation. The enzyme 11- $\beta$-hydroxysteroid dehydrogenase (type-1) (11bHSD1) catalyzes the conversion of the inactive cortisone to cortisol, enabling binding to GR and signaling. Myeloid specific knockouts of $11 \mathrm{bHSD} 1$, preventing endogenous GC signaling in macrophages and neutrophils, result in a more severe arthritis phenotype (90). This is however not limited to macrophages, inhibition of 11bHSD1 increases neutrophil recruitment during peritonitis (91). 
Expansion of GC research into zebrafish models is still in the early stages, and so appears somewhat contradictory. No effect of the GC beclomethasone has been observed on the migratory capacity of macrophages toward the wounding area in an amputation model in zebrafish (92). However in a separate model of wounding, prednisolone reduced macrophage accumulation in both larvae and adults (93). This may be due to the different ligands used, as different ligands have previously been shown to have different transcriptional effects (51). Thus, in most tissue injuries, GC-GR axis appears to be a central pathway in macrophages to regulate the resolution of inflammation and to proceed to tissue repair after injury.

\section{GLUCOCORTICOIDS AND MACROPHAGES-CELLULAR ASPECTS}

\section{GCs Regulate Survival, Migration, and Proliferation of Macrophages}

Maintenance of living immune cells in appropriate numbers is essential to modulate the inflammatory response, and GCs appear to play several roles in the regulation of macrophage life-span. GCs exert anti-apoptotic effects on macrophages: macrophages treated with dexamethasone are more resistant to lipopolysaccharide (LPS)-induced apoptosis (94). Similar results were obtained with other apoptotic stimuli (staurosporine, actinomycin D, or cyclohexine) where GC effects are mediated through ERK1/2 phosphorylation in an adenosine receptor A3dependent-manner $(95,96)$. Moreover, macrophages treated with dexamethasone are smaller with less cytoplasmic extensions (97), which could be related to altered migratory capacity. The capacity of macrophages to move toward the injured area also shapes the inflammatory response. Macrophages treated with hydrocortisone (cortisol) show a decreased capacity to migrate in vitro $(98,99)$. In vivo, a similar effect was observed in a model of lung injury induced by bleomycin, where GCs inhibited macrophage infiltration into the lung (100). Studies using myeloid like cells and whole bone marrow preparations showed that GCs decrease proliferation of cells (including macrophages) in vitro $(101,102)$, but GC impact on proliferation has never been investigated on macrophage cultures. GR activation also has potent effects on nitric oxide (NO) production by macrophages. Initial studies in the J774a.1 macrophage cell line demonstrated that GCs suppress the induction of the NO-generating enzyme, nitric oxide synthase, thus controlling the level of NO produced by the cells in response to an inflammatory stimulus (103). Later studies however, showed that GCs are protective in a mouse model of stroke through increasing NO production in a non-genomic manner. By activating PI3K, GCs rapidly induce NO dependent vasodilation (104). The effects of GCs on NO production were further demonstrated to be dose dependent, with lower doses eliciting an increase in NO, while higher doses reducing the production of NO (105).

Thus, GCs promote macrophage survival in order to switch off inflammation and to sustain late phase of healing. In the following decades, studies have focused on the understanding of the molecular aspects of GC signaling pathways.

\section{GCs and Phagocytosis}

During inflammation, damaged tissue produces cell debris, and releases cytoplasmic proteins into the environment due to cell lysis (106). Before tissue repair can start, debris must be cleared up (106). The clearing process is mainly performed by neutrophils, then macrophages, through phagocytosis of tissue debris, i.e., efferocytosis (106). Since phagocytosis is a major function of macrophages and is an essential trigger of their inflammatory switch (see above section "Macrophage phagocytosis and the resolution of inflammation"), the action of anti-inflammatory treatments on this process is of importance. GCs were detected very early to have an impact on phagocytic activity of macrophages (107). Later on, studies showed in in vitro models using a variety of particles (zymosan, heat-kill yeast, apoptotic neutrophils, latex beads, bacteria) that dexamethasone increases the phagocytic activity of monocytes/macrophages $(95,102,108-115)$. Some of these studies have also shown, using a GR antagonist (RU486), that GC-dependent phagocytosis is also GR dependent $(109,110)$. The increased macrophage phagocytic activity by dexamethasone is annexin 1-FRP1 dependent (116). Annexin 1 belongs to the superfamily of annexin protein, which bind acidic phospholipids in the presence of $\mathrm{Ca}^{2+}$ (116). Annexin A1 is described to be a pro-resolving molecule during inflammation (117). Indeed, when the annexin receptor FRP1 is antagonized by the Bocl compound or in annexin 1-null macrophages, dexamethasone loses its effect on phagocytosis (118).

On closer examination of the phagocytic process, it became clear that GCs induce the up-regulation of several membrane receptors, such as the scavenger receptor CD163, required to detect and bind haptoglobin, a product from hemoglobin degradation $(111,113,114,119)$. The mannose receptor CD206, required for the detection of specific oligosaccharides on the bacterial wall, is also upregulated in macrophages treated by GCs (120). Moreover, GCs upregulate the membrane receptor Mer tyrosine kinase (MerTK) (121), in a C/EBP $\beta$ dependentmanner (122). When mertk is silenced, dexamethasone-induced phagocytosis is reduced (121). MerTK belongs to the Tyro3, Axl, MerTK (TAM) family of tyrosine kinase receptor. It binds to phosphatidyl serine exposed on the surface of apoptotic cells $(121,122)$. MerTK is also responsible for the phagocytosis of protein S-opsonized apoptotic neutrophils by GC-treated macrophages (123). The other members of the TAM family do not seem to be necessary for GCinduced phagocytosis, as Tyro3 deficient, or Axl deficient mice are able to successfully clear apoptotic cells in response to GCs (124). Interestingly, in a model of serum-transfer induced arthritis, Axl, MerTK, and CD163 upregulation in macrophages requires GR function on synovial fibroblasts, indicating their regulation through cross-talk between local cells (72). Finally, GCs regulate the C/EBP $\beta$-dependent expression of nuclear receptors (liver $\mathrm{X}$ receptor [LXR], retinoid X receptor $\alpha[\mathrm{RXR} \alpha]$ and peroxisome proliferator-activated receptor $\delta$ [PPAR $\delta]$ ), which are required for prolonged phagocytosis of macrophages (122). Thus, GCs act on several steps of phagocytosis and their effects are mediated through various signaling pathways. 


\section{GLUCOCORTICOIDS AND GENE EXPRESSION IN MACROPHAGES-MOLECULAR ASPECTS}

Although the first effects of GCs on macrophages were reported in 1950, the literature about their specific effects on this cell type is not abundant (see section GCs on macrophages: expression of anti-inflammatory effectors). In 1950, Dougherty and colleagues showed in a model of local inflammation in mice that cortisone treatment reduces the number of macrophages in the inflamed area (125). In another model of skin inflammation induced by injection of turpentine, Spain et al. showed that cortisone inhibits the formation of granulation in the inflamed area (granulations corresponding to macrophages according to the authors) and a decrease of carbon particle phagocytosis when administrated early during the inflammatory response (107). However, the experiments done by Gell and Hinde on intraperitoneal macrophages exposed to bacteria showed that cortisone does not alter either the number of macrophages or their phagocytic capacity (126).

\section{GCs on Macrophages: Expression of Anti-inflammatory Effectors}

It is well-known that macrophages can exert pleiotropic functions through the secretion of a variety of factors. Macrophages are highly versatile, and may secrete pro-inflammatory, antiinflammatory, or other factors necessary at each step of the inflammatory response. GCs decrease the secretion of the pro-inflammatory cytokines TNFa $(94,127)$, IL-1, IL-6 in macrophages exposed to IFN $\gamma(100,113)$. Monocytes treated with GCs increase their secretion of IL-10 and TGF $\beta(128,129)$ and express high levels of the anti-inflammatory membrane markers CD206 (120), CD163 (95, 111, 113, 114, 119, 130) and CD169 $(95,131)$. GC anti-inflammatory effects are partly mediated by Mitogen-activated protein kinase phosphatase- 1 (MKP-1) in macrophages, as it was GC-driven inhibition of IL-6 expression was abrogated in MKP-1 deficient macrophages (132).

Furthermore, macrophages exposed to GCs secrete molecules which have direct functions on the extracellular matrix and therefore participate to matrix remodeling during the late phase of the inflammatory response. The production of elastase, collagenase and plasminogen activator (whose secretion is elevated in pro-inflammatory macrophages and which are required to degrade extracellular matrix) is reduced in macrophages treated with GCs $(133,134)$. On the contrary, macrophages exhibiting an alternatively activated status (i.e., IL-4 driven) secrete more fibronectin when treated with GCs, participating in matrix remodeling at the time of tissue repair $(114,135,136)$.

\section{GC Action on Macrophages: Regulation of Gene Expression}

GCs act through either the GR dimer or GR monomer, entirely depending on the gene regulated. For example, in dermatitis, GR dimerization is required to shut down the expression of the pro-inflammatory cytokines IL-1 $\beta$ and MCP- 1 whereas TNF $\alpha$ downregulation induced by GCs does not require GR dimerization (87). GCs also modulate chromatin architecture, mainly closing down access to genes involved in inflammation, preventing access to other transcription factors $(137,138)$.

Importantly, the gene regulatory actions of GCs depend on the activation state of macrophages. Indeed, more than 10,000 genomic GR binding sites are induced by dexamethasone in resting macrophages with more than 5,400 known GR target genes, while in macrophages pre-treated with GCs, then LPS, there is a rewiring of GR binding, with 13,000 binding sites and more than 6,400 GR target genes identified (139). Furthermore, GCs regulate a different set of genes in macrophages activated with LPS or IFN $\gamma$ indicating that genes are regulated by GCs are also dependent on the inflammatory stimulus (130). LPS stimulation also increases the ability of GR to bind DNA indicating that pro-inflammatory stimulation potentiates GR DNA binding, likely through the generation of more potential binding loci $(138,139)$. Oh et al. also demonstrated that pretreatment compared to post-treatment of GCs with LPS results in a differential effect on gene regulation. The number and location of GR binding sites and p 65 binding sites were different between the GC pre-treated cells and the cells treated with LPS first, then GCs (138). Furthermore, another GR partner, the Glucocorticoid Receptor-Interacting Protein (GRIP) 1, also known as nuclear receptor co-activator 2 (NCOA2) is required for the acquisition of the anti-inflammatory phenotype of macrophages (140). GRIP1 can be phosphorylated by Cyclin-Dependent Kinase 9 (CDK9) in a GR dependent-manner. Phosphorylated GRIP1, in association with GR, binds GREs to induce the expression of anti-inflammatory genes. However, phosphorylated GRIP1 is not observed in GR repressed sites such as of IL1 $a$ or $I L 1 b$, indicating that phosphorylated GRIP1 only acts on positive transcription of anti-inflammatory genes, and it is likely that the phosphorylation status of GRIP1 can modulate GR transcriptional activity (141). Our understanding of the role of GR as an anti-inflammatory transcription factor is still evolving, and with new technologies, the actions of GR will become clearer with time.

\section{The GC Effector GILZ in Macrophages}

GC-mediated anti-inflammatory effects are known to be partly mediated through the regulation of the expression of specific proteins that in turn modulate inflammatory signaling. A very well-studied example is Glucocorticoid-Induced Leucine Zipper (GILZ). Originally found expressed in lymphoid tissues (thymocyte, spleen, lymph nodes) treated by dexamethasone (142), GILZ is a major regulator of GC effects in a variety of cells. GILZ was also found to be expressed by macrophages in liver and lung treated by dexamethasone (143). In the THP1 macrophage cell line, dexamethasone induces Gilz mRNA expression after only $30 \mathrm{~min}$ of treatment (143). GILZ acts by binding the p65 subunit of the NFKB complex to shut down its activity (143). GILZ also inhibits the expression of the Toll like receptor 2 (TLR2), thus limiting the recognition of bacterial components and the associated inflammatory signaling (143). 
GCs however also enhance the expression of TLR2 in a celltype specific manner $(144,145)$, suggesting that GILZ may act as a homeostatic brake on GC enhanced TLR2 signaling. Furthermore, GC-induced GILZ expression is strongly reduced in annexin A1 deficient macrophages, therefore preventing the downregulation of the pro-inflammatory cytokines IL-1, IL-6, and $\mathrm{TNF} \alpha(146,147)$. This regulation is not dependent of the annexin receptor FRP (146), thus, the exact mechanism by which annexin regulates Gilz expression remains to be elucidated.

\section{CONCLUSION}

The effects of GCs on macrophages, especially in the broader context of resolution of inflammation during tissue repair, are not as well-understood as one would assume. GCs play key roles in the regulation of macrophage homeostatic functions, as well as the macrophage function as innate immunity cells. GR however, does not act alone. In association with several partners including other transcription factors (C/EBP $\beta$, PPARs, NFкB) or proteins that modulate its activity (GRIP1), GR controls the functional properties of macrophages to resolve inflammation and tissue damage. Finally, GCs regulate the expression of a

\section{REFERENCES}

1. Gordon S. Alternative activation of macrophages. Nat Rev Immunol. (2003) 3:23-35. doi: 10.1038/nri978

2. Mosser DM, Edwards JP. Exploring the full spectrum of macrophage activation. Nat Rev Immunol. (2008) 8:958-69. doi: 10.1038/nri2448

3. Sica A, Mantovani A. Macrophage plasticity and polarization: in vivo veritas. J Clin Invest. (2012) 122:787-95. doi: 10.1172/JCI 59643

4. Xue J, Schmidt SV, Sander J, Draffehn A, Krebs W, Quester I, et al. Transcriptome-based network analysis reveals a spectrum model of human macrophage activation. Immunity. (2014) 40:274-88. doi: 10.1016/j.immuni.2014.01.006

5. Murray PJ, Judith AE, Subhra BK, Edward FA, Derek GW, Goerdt S, et al. Macrophage activation and polarization: nomenclature and experimental guidelines. Immunity. (2014) 41:14-20. doi: 10.1016/j.immuni.2014.06.008

6. Varga T, Mounier R, Horvath A, Cuvellier S, Dumont F, Poliska S, et al. Highly dynamic transcriptional signature of distinct macrophage subsets during sterile inflammation, resolution, and tissue repair. J Immunol. (2016) 196:4771-82. doi: 10.4049/jimmunol.1502490

7. Epelman S, Lavine KJ, Randolph GJ. Origin and functions of tissue macrophages. Immunity. (2014) 41:21-35. doi: 10.1016/ j.immuni.2014.06.013

8. Chazaud B. Macrophages: supportive cells for tissue repair and regeneration. Immunobiology. (2014) 219:172-8. doi: 10.1016/j.imbio.2013.09.001

9. Nahrendorf M, Pittet MJ, Swirski FK. Monocytes: protagonists of infarct inflammation and repair after myocardial infarction. Circulation. (2010) 121:2437-45. doi: 10.1161/CIRCULATIONAHA.109.916346

10. Michelucci A, Heurtaux T, Grandbarbe L, Morga E, Heuschling P. Characterization of the microglial phenotype under specific pro-inflammatory and anti-inflammatory conditions: effects of oligomeric and fibrillar amyloid- $\beta$. J Neuroimmunol. (2009) 210:3-12. doi: 10.1016/j.jneuroim.2009.02.003

11. Fumagalli M. Role of purinergic signalling in neuro-immune cells and adult neural progenitors. Front Biosci. (2011) 16:2326. doi: 10.2741/3856

12. Pellicoro A, Ramachandran P, Iredale JP, Fallowfield JA. Liver fibrosis and repair: immune regulation of wound healing in a solid organ. Nat Rev Immunol. (2014) 14:181-94. doi: 10.1038/nri3623 huge number of genes that are essential to relay their antiinflammatory properties such as Gilz and Annexin al. Despite 60 years of work on GCs, we are still discovering further molecular mechanisms that govern their actions. The role of the inflammatory context $(138,139)$ and species differences in GC mediated gene regulation (148) highlight that further investigation is necessary to decipher, for each situation, how GCs operate to regulate gene expression, and therefore control macrophage function.

\section{AUTHOR CONTRIBUTIONS}

TD, GC, RM, JT, and BC writing and editing of the manuscript.

\section{FUNDING}

BC and JT labs were recently founded by Fondation pour la Recherche Médicale (Equipe FRM DEQ20140329495), Agence Nationale de la Recherche ANR-15-CE15-0024, Deutsche Forschungsgemeinschaft DFG TU 220/13-1 and DFG INST 40/492-2 SFB 1149, and Hubert Curien PROCOPE/Deutscher Akademischer Austauschdienst (DAAD) exchange program.

13. Ricardo SD, van Goor H, Eddy AA. Macrophage diversity in renal injury and repair. J Clin Invest. (2008) 118:3522-30. doi: 10.1172/JCI36150

14. Rogers NM, Ferenbach DA, Isenberg JS, Thomson AW, Hughes J. Dendritic cells and macrophages in the kidney: a spectrum of good and evil. Nat Rev Nephrol. (2014) 10:625-43. doi: 10.1038/nrneph.2014.170

15. Arnold L, Henry A, Poron F, Baba-Amer Y, van Rooijen N, Plonquet A, et al. Inflammatory monocytes recruited after skeletal muscle injury switch into antiinflammatory macrophages to support myogenesis. J Exp Med. (2007) 204:1057-69. doi: 10.1084/jem.20070075

16. Mounier R, Théret M, Arnold L, Cuvellier S, Bultot L, Göransson O, et al. AMPK $\alpha 1$ regulates macrophage skewing at the time of resolution of inflammation during skeletal muscle regeneration. Cell Metab. (2013) 18:251-64. doi: 10.1016/j.cmet.2013.06.017

17. Saclier M, Yacoub-Youssef H, Mackey AL, Arnold L, Ardjoune H, Magnan M, et al. Differentially activated macrophages orchestrate myogenic precursor cell fate during human skeletal muscle regeneration. Stem Cells. (2013) 31:384-96. doi: 10.1002/stem.1288

18. Varga T, Mounier R, Gogolak P, Poliska S, Chazaud B, Nagy L. Tissue LyC6macrophages are generated in the absence of circulating LyC6- monocytes and Nur77 in a model of muscle regeneration. J Immunol. (2013) 191:5695701. doi: 10.4049/jimmunol.1301445

19. Yin H, Price F, Rudnicki MA. Satellite cells and the muscle stem cell niche. Physiol Rev. (2013) 93:23-67. doi: 10.1152/physrev.00043.2011

20. Hardy D, Besnard A, Latil M, Jouvion G, Briand D, Thépenier C, et al. Comparative study of injury models for studying muscle regeneration in mice. PLoS ONE. (2016) 11:e0147198. doi: 10.1371/journal.pone.0147198

21. Latroche C, Weiss-Gayet M, Muller L, Gitiaux C, Leblanc P, Liot S, et al. Coupling between myogenesis and angiogenesis during skeletal muscle regeneration is stimulated by restorative macrophages. Stem Cell Rep. (2017) 9:2018-33. doi: 10.1016/j.stemcr.2017.10.027

22. Lemos DR, Babaeijandaghi F, Low M, Chang C-K, Lee ST, Fiore D, et al. Nilotinib reduces muscle fibrosis in chronic muscle injury by promoting TNF-mediated apoptosis of fibro/adipogenic progenitors. Nat Med. (2015) 21:786-94. doi: 10.1038/nm.3869

23. Uderhardt S, Martins AJ, Tsang JS, Lämmermann T, Germain RN. Resident macrophages cloak tissue microlesions to prevent neutrophil-driven inflammatory damage. Cell. (2019) 177:541-55.e17. doi: 10.1016/j.cell.2019.02.028 
24. Heredia JE, Mukundan L, Chen FM, Mueller AA, Deo RC, Locksley RM, et al. Type 2 innate signals stimulate fibro/adipogenic progenitors to facilitate muscle regeneration. Cell. (2013) 153:376-88. doi: 10.1016/j.cell.2013.02.053

25. Burzyn D, Kuswanto W, Kolodin D, Shadrach JL, Cerletti M, Jang Y, et al. A special population of regulatory $\mathrm{T}$ cells potentiates muscle repair. Cell. (2013) 155:1282-95. doi: 10.1016/j.cell.2013.10.054

26. Shireman PK, Contreras-Shannon V, Ochoa O, Karia BP, Michalek JE, McManus LM. MCP-1 deficiency causes altered inflammation with impaired skeletal muscle regeneration. J Leukoc Biol. (2007) 81:775-85. doi: 10.1189/jlb.0506356

27. Sun D, Martinez CO, Ochoa O, Ruiz-Willhite L, Bonilla JR, Centonze VE, et al. Bone marrow-derived cell regulation of skeletal muscle regeneration. Faseb J. (2009) 23:382-95. doi: 10.1096/fj.07-095901

28. Chazaud B, Sonnet C, Lafuste P, Bassez G, Rimaniol A-C, Poron F, et al. Satellite cells attract monocytes and use macrophages as a support to escape apoptosis and enhance muscle growth. J Cell Biol. (2003) 163:1133-43. doi: $10.1083 /$ jcb. 200212046

29. Sonnet C. Human macrophages rescue myoblasts and myotubes from apoptosis through a set of adhesion molecular systems. J Cell Sci. (2006) 119:2497-507. doi: 10.1242/jcs.02988

30. Juban G, Saclier M, Yacoub-Youssef H, Kernou A, Arnold L, Boisson $\mathrm{C}$, et al. AMPK activation regulates LTBP4-dependent TGF- $\beta 1$ secretion by pro-inflammatory macrophages and controls fibrosis in duchenne muscular dystrophy. Cell Rep. (2018) 25:2163-76.e2166. doi: 10.1016/j.celrep.2018.10.077

31. Fadok VA, Bratton DL, Konowal A, Freed PW, Westcott JY, Henson PM. Macrophages that have ingested apoptotic cells in vitro inhibit proinflammatory cytokine production through autocrine/paracrine mechanisms involving TGF-beta, PGE2, and PAF. J Clin Invest. (1998) 101:890-8. doi: 10.1172/JCI1112

32. Freire-de-Lima CG, Xiao YQ, Gardai SJ, Bratton DL, Schiemann WP, Henson PM. Apoptotic cells, through transforming growth factor- $\beta$, coordinately induce anti-inflammatory and suppress pro-inflammatory eicosanoid and NO synthesis in murine macrophages. J Biol Chem. (2006) 281:38376-84. doi: 10.1074/jbc.M605146200

33. Weigert A. Apoptotic cells promote macrophage survival by releasing the antiapoptotic mediator sphingosine-1-phosphate. Blood. (2006) 108:163542. doi: 10.1182/blood-2006-04-014852

34. Ochoa O, Sun D, Reyes-Reyna SM, Waite LL, Michalek JE, McManus LM, et al. Delayed angiogenesis and VEGF production in CCR2-/- mice during impaired skeletal muscle regeneration. Am J Physiol-Regul Integr Comp Physiol. (2007) 293:R651-61. doi: 10.1152/ajpregu.00069.2007

35. Cheng M, Nguyen M-H, Fantuzzi G, Koh TJ. Endogenous interferon- $\gamma$ is required for efficient skeletal muscle regeneration. Am J Physiol-Cell Physiol. (2008) 294:C1183-91. doi: 10.1152/ajpcell.00568.2007

36. Perdiguero E, Sousa-Victor P, Ruiz-Bonilla V, Jardí M, Caelles C, Serrano $\mathrm{AL}$, et al. p38/MKP-1-regulated AKT coordinates macrophage transitions and resolution of inflammation during tissue repair. J Cell Biol. (2011) 195:307-22. doi: $10.1083 /$ jcb.201104053

37. Chazaud B. Inflammation during skeletal muscle regeneration and tissue remodeling: application to exercise-induced muscle damage management. Immunol Cell Biol. (2016) 94:140-5. doi: 10.1038/icb.2015.97

38. Ruffell D, Mourkioti F, Gambardella A, Kirstetter P, Lopez RG, Rosenthal $\mathrm{N}$, et al. A CREB-C/EBP cascade induces M2 macrophage-specific gene expression and promotes muscle injury repair. Proc Natl Acad Sci USA. (2009) 106:17475-80. doi: 10.1073/pnas.0908641106

39. Cain DW, Cidlowski JA. Immune regulation by glucocorticoids. Nat Rev Immunol. (2017) 17:233-47. doi: 10.1038/nri.2017.1

40. Gjerstad JK, Lightman SL, Spiga F. Role of glucocorticoid negative feedback in the regulation of HPA axis pulsatility. Stress. (2018) 21:403-16. doi: 10.1080/10253890.2018.1470238

41. Malek H, Ebadzadeh MM, Safabakhsh R, Razavi A, Zaringhalam J. Dynamics of the HPA axis and inflammatory cytokines: insights from mathematical modeling. Comput Biol Med. (2015) 67:1-12. doi: 10.1016/j.compbiomed.2015.09.018

42. Sternberg EM. Neural regulation of innate immunity: a coordinated nonspecific host response to pathogens. Nat Rev Immunol. (2006) 6:318-28. doi: $10.1038 /$ nri1810
43. Hollenberg SM, Weinberger C, Ong ES, Cerelli G, Oro A, Lebo R, et al. Primary structure and expression of a functional human glucocorticoid receptor cDNA. Nature. (1985) 318:635-41. doi: 10.1038/318635a0

44. Leung DYM, Hamid Q, Vottero A, Szefler SJ, Surs W, Minshall E, et al. Association of glucocorticoid insensitivity with increased expression of glucocorticoid receptor. J Exp Med. (1997) 186:1567-74. doi: 10.1084/jem.186.9.1567

45. Caratti G, Matthews L, Poolman T, Kershaw S, Baxter M, Ray D. Glucocorticoid receptor function in health and disease. Clin Endocrinol. (2015) 83:441-8. doi: 10.1111/cen.12728

46. Morgan DJ, Poolman TM, Williamson AJ, Wang Z, Clark NR, Ma'ayan A, et al. Glucocorticoid receptor isoforms direct distinct mitochondrial programs to regulate ATP production. Sci Rep. (2016) 6:26419. doi: $10.1038 /$ srep26419

47. Haarman EG, Kaspers GJ, Pieters R, Rottier MM, Veerman AJ. Glucocorticoid receptor alpha, beta and gamma expression vs in vitro glucocorticod resistance in childhood leukemia. Leukemia. (2004) 18:530-7. doi: 10.1038/sj.leu.2403225

48. Kumar R, Thompson EB. The structure of the nuclear hormone receptors. Steroids. (1999) 64:310-9. doi: 10.1016/S0039-128X(99)00014-8

49. McMaster A, Ray DW. Drug Insight: selective agonists and antagonists of the glucocorticoid receptor. Nat Clin Pract Endocrinol Metab. (2008) 4:91-101. doi: $10.1038 /$ ncpendmet0745

50. Nicolaides NC, Galata Z, Kino T, Chrousos GP, Charmandari E. The human glucocorticoid receptor: Molecular basis of biologic function. Steroids. (2010) 75:1-12. doi: 10.1016/j.steroids.2009.09.002

51. Weikum ER, Knuesel MT, Ortlund EA, Yamamoto KR. Glucocorticoid receptor control of transcription: precision and plasticity via allostery. Nat Rev Mol Cell Biol. (2017) 18:159-74. doi: 10.1038/nrm.2016.152

52. Lim HW, Uhlenhaut NH, Rauch A, Weiner J, Hubner S, Hubner N, et al. Genomic redistribution of GR monomers and dimers mediates transcriptional response to exogenous glucocorticoid in vivo. Genome Res. (2015) 25:836-44. doi: 10.1101/gr.188581.114

53. Ray A, Prefontaine KE. Physical association and functional antagonism between the p65 subunit of transcription factor NF-cB and the glucocorticoid receptor. Proc Natl Acad Sci USA. (1994) 91:752-6. doi: 10.1073/pnas.91.2.752

54. Miner JN, Yamamoto KR. The basic region of AP-1 specifies glucocorticoid receptor activity at a composite response element. Genes Dev. (1992) 6:2491501. doi: 10.1101/gad.6.12b.2491

55. Weikum ER, de Vera IMS, Nwachukwu JC, Hudson WH, Nettles KW, Kojetin DJ, et al. Tethering not required: the glucocorticoid receptor binds directly to activator protein-1 recognition motifs to repress inflammatory genes. Nucleic Acids Res. (2017) 45:8596-608. doi: 10.1093/nar/gkx509

56. Xavier AM, Anunciato AK, Rosenstock TR, Glezer I. Gene expression control by glucocorticoid receptors during innate immune responses. Front Endocrinol. (2016) 7:31. doi: 10.3389/fendo.2016.00031

57. Scheschowitsch K, Leite JA, Assreuy J. New insights in glucocorticoid receptor signaling-more than just a ligand-binding receptor. Front Endocrinol. (2017) 8:16. doi: 10.3389/fendo.2017.00016

58. Whirledge S, DeFranco DB. Glucocorticoid signaling in health and disease: insights from tissue-specific GR knockout mice. Endocrinology. (2018) 159:46-64. doi: 10.1210/en.2017-00728

59. Panettieri RA, Schaafsma D, Amrani Y, Koziol-White C, Ostrom R, Tliba O. Non-genomic effects of glucocorticoids: an updated view. Trends Pharmacol Sci. (2019) 40:38-49. doi: 10.1016/j.tips.2018.11.002

60. David DS, Grieco MH, Cushman P. Adrenal glucocorticoids after twenty years. J Chron Dis. (1970) 22:637-711. doi: 10.1016/0021-9681(70) 90078-0

61. Opherk C, Tronche F, Kellendonk C, Kohlmuller D, Schulze A, Schmid $\mathrm{W}$, et al. Inactivation of the glucocorticoid receptor in hepatocytes leads to fasting hypoglycemia and ameliorates hyperglycemia in streptozotocin-induced diabetes mellitus. Mol Endocrinol. (2004) 18:1346-53. doi: 10.1210/me.2003-0283

62. Lemke U, Krones-Herzig A, Berriel Diaz M, Narvekar P, Ziegler A, Vegiopoulos A, et al. The glucocorticoid receptor controls hepatic dyslipidemia through Hes1. Cell Metab. (2008) 8:212-23. doi: 10.1016/j.cmet.2008.08.001 
63. Caratti G, Iqbal M, Hunter L, Kim D, Wang P, Vonslow RM, et al. REVERBa couples the circadian clock to hepatic glucocorticoid action. J Clin Invest. (2018) 128:4454-71. doi: 10.1172/JCI 96138

64. Baida G, Bhalla P, Kirsanov K, Lesovaya E, Yakubovskaya M, Yuen K, et al. REDD1 functions at the crossroads between the therapeutic and adverse effects of topical glucocorticoids. EMBO Mol Med. (2015) 7:42-58. doi: 10.15252/emmm.201404601

65. Baida G, Bhalla P, Yemelyanov A, Stechschulte LA, Shou W, Readhead $B$, et al. Deletion of the glucocorticoid receptor chaperone FKBP51 prevents glucocorticoid-induced skin atrophy. Oncotarget. (2018) 9:3477283. doi: 10.18632/oncotarget. 26194

66. Gilson H, Schakman O, Combaret L, Lause P, Grobet L, Attaix D, et al. Myostatin gene deletion prevents glucocorticoid-induced muscle atrophy. Endocrinology. (2007) 148:452-60. doi: 10.1210/en.2006-0539

67. Rauch A, Seitz S, Baschant U, Schilling AF, Illing A, Stride B, et al. Glucocorticoids suppress bone formation by attenuating osteoblast differentiation via the monomeric glucocorticoid receptor. Cell Metab. (2010) 11:517-31. doi: 10.1016/j.cmet.2010.05.005

68. Newell-Price J, Bertagna X, Grossman AB, Nieman LK. Cushing's syndrome. Lancet. (2006) 367:1605-17. doi: 10.1016/S0140-6736(06)68699-6

69. Lee IT, Atuahene A, Egritag HE, Wang L, Donovan M, Buettner C, et al. Active cushing disease is characterized by increased adipose tissue macrophage presence. J Clin Endocrinol Metab. (2019) 104:2453-61. doi: 10.1210/jc.2018-02552

70. Baschant U, Lane NE, Tuckermann J. The multiple facets of glucocorticoid action in rheumatoid arthritis. Nat Rev Rheumatol. (2012) 8:645-55. doi: 10.1038/nrrheum.2012.166

71. Baschant U, Frappart L, Rauchhaus U, Bruns L, Reichardt HM, Kamradt T, et al. Glucocorticoid therapy of antigen-induced arthritis depends on the dimerized glucocorticoid receptor in T cells. Proc Natl Acad Sci USA. (2011) 108:19317-22. doi: 10.1073/pnas.1105857108

72. Koenen M, Culemann S, Vettorazzi S, Caratti G, Frappart L, Baum W, et al. Glucocorticoid receptor in stromal cells is essential for glucocorticoidmediated suppression of inflammation in arthritis. Ann Rheum Dis. (2018) 77:1610-8. doi: 10.1136/annrheumdis-2017-212762

73. Kleiman A, Hubner S, Rodriguez Parkitna JM, Neumann A, Hofer S, Weigand MA, et al. Glucocorticoid receptor dimerization is required for survival in septic shock via suppression of interleukin-1 in macrophages. Faseb J. (2012) 26:722-9. doi: 10.1096/fj.11-192112

74. Vandevyver S, Dejager L, Van Bogaert T, Kleyman A, Liu Y, Tuckermann $\mathrm{J}$, et al. Glucocorticoid receptor dimerization induces MKP1 to protect against TNF-induced inflammation. J Clin Invest. (2012) 122:2130-40. doi: 10.1172/JCI60006

75. Ballegeer M, Van Looveren K, Timmermans S, Eggermont M, Vandevyver S, Thery F, et al. Glucocorticoid receptor dimers control intestinal STAT1 and TNF-induced inflammation in mice. J Clin Invest. (2018) 128:3265-79. doi: 10.1172/JCI96636

76. Roohk DJ, Mascharak S, Khambatta C, Leung H, Hellerstein M, Harris C. Dexamethasone-mediated changes in adipose triacylglycerol metabolism are exaggerated, not diminished, in the absence of a functional GR dimerization domain. Endocrinology. (2013) 154:1528-39. doi: 10.1210/en.2011-1047

77. Jacome-Galarza CE, Percin GI, Muller JT, Mass E, Lazarov T, Eitler J, et al. Developmental origin, functional maintenance and genetic rescue of osteoclasts. Nature. (2019) 568:541-5. doi: 10.1038/s41586-019-1105-7

78. Teitelbaum SL, Malone JD, Kahn AJ. Glucocorticoid enhancement of bone resorption by rat peritoneal macrophages in vitro. Endocrinology. (1981) 108:795-9. doi: 10.1210/endo-108-3-795

79. Bar-Shavit Z, Kahn AJ, Pegg LE, Stone KR, Teitelbaum SL. Glucocorticoids modulate macrophage surface oligosaccharides and their bone binding activity. J Clin Invest. (1984) 73:1277-83. doi: 10.1172/JCI111329

80. Conaway HH, Henning P, Lie A, Tuckermann J, Lerner UH. Activation of dimeric glucocorticoid receptors in osteoclast progenitors potentiates RANKL induced mature osteoclast bone resorbing activity. Bone. (2016) 93:43-54. doi: 10.1016/j.bone.2016.08.024

81. Hofbauer LC, Gori F, Riggs BL, Lacey DL, Dunstan CR, Spelsberg TC, et al. Stimulation of osteoprotegerin ligand and inhibition of osteoprotegerin production by glucocorticoids in human osteoblastic lineage cells: potential paracrine mechanisms of glucocorticoid-induced osteoporosis. Endocrinology. (1999) 140:4382-9. doi: 10.1210/endo.140.10.7034

82. Thiele S, Ziegler N, Tsourdi E, De Bosscher K, Tuckermann JP, Hofbauer LC, et al. Selective glucocorticoid receptor modulation maintains bone mineral density in mice. J Bone Min Res. (2012) 27:2242-50. doi: 10.1002/jbmr.1688

83. Hofbauer LC, Zeitz U, Schoppet M, Skalicky M, Schüler C, Stolina M, et al. Prevention of glucocorticoid-induced bone loss in mice by inhibition of RANKL. Arthritis Rheum. (2009) 60:1427-37. doi: 10.1002/art.24445

84. Jia D, O’Brien CA, Stewart SA, Manolagas SC, Weinstein RS. Glucocorticoids act directly on osteoclasts to increase their life span and reduce bone density. Endocrinology. (2006) 147:5592-9. doi: 10.1210/en.2006-0459

85. Kim H-J, Zhao H, Kitaura H, Bhattacharyya S, Brewer JA, Muglia LJ, et al. Glucocorticoids suppress bone formation via the osteoclast. J Clin Invest. (2006) 116:2152-60. doi: 10.1172/JCI28084

86. Weinstein RS, Chen J-R, Powers CC, Stewart SA, Landes RD, Bellido T, et al. Promotion of osteoclast survival and antagonism of bisphosphonateinduced osteoclast apoptosis by glucocorticoids. J Clin Invest. (2002) 109:1041-8. doi: 10.1172/JCI0214538

87. Tuckermann JP, Kleiman A, Moriggl R, Spanbroek R, Neumann A, Illing A, et al. Macrophages and neutrophils are the targets for immune suppression by glucocorticoids in contact allergy. J Clin Invest. (2007) 117:1381-90. doi: $10.1172 / \mathrm{JCI} 28034$

88. Galuppo P, Vettorazzi S, Hovelmann J, Scholz CJ, Tuckermann JP, Bauersachs J, et al. The glucocorticoid receptor in monocyte-derived macrophages is critical for cardiac infarct repair and remodeling. Faseb J. (2017) 31:5122-32. doi: 10.1096/fj.201700317R

89. Meers GK, Bohnenberger H, Reichardt HM, Lühder F, Reichardt SD. Impaired resolution of DSS-induced colitis in mice lacking the glucocorticoid receptor in myeloid cells. PLoS ONE. (2018) 13:e0190846. doi: 10.1371/journal.pone.0190846

90. Zhang Z, Coutinho AE, Man TY, Kipari TMJ, Hadoke PWF, Salter DM, et al. Macrophage $11 \beta$-HSD-1 deficiency promotes inflammatory angiogenesis. $J$ Endocrinol. (2017) 234:291-9. doi: 10.1530/JOE-17-0223

91. Coutinho AE, Kipari TM, Zhang Z, Esteves CL, Lucas CD, Gilmour JS, et al. $11 \beta$-hydroxysteroid dehydrogenase type 1 is expressed in neutrophils and restrains an inflammatory response in male mice. Endocrinology. (2016) 157:2928-36. doi: 10.1210/en.2016-1118

92. Chatzopoulou A, Heijmans JP, Burgerhout E, Oskam N, Spaink HP, Meijer $\mathrm{AH}$, et al. Glucocorticoid-induced attenuation of the inflammatory response in zebrafish. Endocrinology. (2016) 157:2772-84. doi: 10.1210/en.2015-2050

93. Geurtzen K, Vernet A, Freidin A, Rauner M, Hofbauer LC, Schneider JE, et al. Immune suppressive and bone inhibitory effects of prednisolone in growing and regenerating zebrafish tissues. J Bone Min Res. (2017) 32:247688. doi: 10.1002/jbmr.3231

94. Luedke CE, Cerami A. Interferon-gamma overcomes glucocorticoid suppression of cachectin/tumor necrosis factor biosynthesis by murine macrophages. J Clin Invest. (1990) 86:1234-40. doi: 10.1172/JCI114829

95. Ehrchen J, Steinmuller L, Barczyk K, Tenbrock K, Nacken W, Eisenacher $\mathrm{M}$, et al. Glucocorticoids induce differentiation of a specifically activated, anti-inflammatory subtype of human monocytes. Blood. (2007) 109:1265-74. doi: 10.1182/blood-2006-02-001115

96. Barczyk K, Ehrchen J, Tenbrock K, Ahlmann M, Kneidl J, Viemann D, et al. Glucocorticoids promote survival of anti-inflammatory macrophages via stimulation of adenosine receptor A3. Blood. (2010) 116:446-55. doi: 10.1182/blood-2009-10-247106

97. Norton JM, Munck A. In vitro actions of glucocorticoids on murine macrophages: effects on glucose transport and metabolism, growth in culture, and protein synthesis. J Immunol. (1980) 125:259-66.

98. Balow JE, Rosenthal AS. Glucocorticoid suppression of macrophage migration inhibitory factor. J Exp Med. (1973) 137:1031-41. doi: 10.1084/jem.137.4.1031

99. Prokic LM, Vilic IM. Effect of prednisolone in vitro on the migration ability of peritoneal macrophages in rats. Experientia. (1983) 39:1133-4. doi: 10.1007/BF01943145

100. Khalil N, Whitman C, Zuo L, Danielpour D, Greenberg A. Regulation of alveolar macrophage transforming growth factor-beta secretion by corticosteroids in bleomycin-induced pulmonary inflammation in the rat. $J$ Clin Invest. (1993) 92:1812-8. doi: 10.1172/JCI116771 
101. Miller SC, Melnykovych G. Inhibition by glucocorticoids of endocytosis in a macrophage-like cell line. J Cell Biochem. (1982) 18:423-31. doi: 10.1002/jcb.1982.240180404

102. Shezen E, Shirman M, Goldman R. Opposing effects of dexamethasone on the clonal growth of granulocyte and macrophage progenitor cells and on the phagocytic capability of mononuclear phagocytes at different stages of differentiation. J Cell Physiol. (1985) 124:545-53. doi: $10.1002 /$ jcp. 1041240326

103. Di Rosa M, Radomski M, Carnuccio R, Moncada S. Glucocorticoids inhibit the induction of nitric oxide synthase in macrophages. Biochem Biophys Res Commun. (1990) 172:1246-52. doi: 10.1016/0006-291X(90)91583-E

104. Limbourg FP, Huang Z, Plumier J-C, Simoncini T, Fujioka M, Tuckermann J, et al. Rapid nontranscriptional activation of endothelial nitric oxide synthase mediates increased cerebral blood flow and stroke protection by corticosteroids. J Clin Invest. (2002) 110:1729-38. doi: 10.1172/JCI0215481

105. Lim HY, Müller N, Herold MJ, van den Brandt J, Reichardt HM. Glucocorticoids exert opposing effects on macrophage function dependent on their concentration. Immunology. (2007) 122:47-53. doi: 10.1111/j.1365-2567.2007.02611.x

106. Morioka S, Maueroder C, Ravichandran KS. Living on the Edge: efferocytosis at the Interface of homeostasis and pathology. Immunity. (2019) 50:1149-62. doi: 10.1016/j.immuni.2019.04.018

107. Spain DM, Molomut N, Haber A. Biological studies on cortisone in mice. Science. (1950) 112:335-7. doi: 10.1126/science.112.2908.335

108. Lombardi L, Forte N, Paradisi F. Effect of pretreatment with prednisolone on the phagocytic activity of mouse peritoneal macrophages in vitro. Experientia. (1978) 34:1503-4. doi: 10.1007/BF01932377

109. Liu Y, Cousin JM, Hughes J, Van Damme J, Seckl JR, Haslett C, et al. Glucocorticoids promote nonphlogistic phagocytosis of apoptotic leukocytes. J Immunol. (1999) 162:3639-46.

110. van der Goes A, Hoekstra K, van den Berg TK, Dijkstra CD. Dexamethasone promotes phagocytosis and bacterial killing by human monocytes/macrophages in vitro. J Leukoc Biol. (2000) 67:801-7. doi: 10.1002/jlb.67.6.801

111. Giles KM, Ross K, Rossi AG, Hotchin NA, Haslett C, Dransfield I. Glucocorticoid augmentation of macrophage capacity for phagocytosis of apoptotic cells is associated with reduced p130Cas expression, loss of paxillin/pyk2 phosphorylation, and high levels of active Rac. J Immunol. (2001) 167:976-86. doi: 10.4049/jimmunol.167.2.976

112. Heasman SJ, Giles KM, Ward C, Rossi AG, Haslett C, Dransfield I. Glucocorticoid-mediated regulation of granulocyte apoptosis and macrophage phagocytosis of apoptotic cells: implications for the resolution of inflammation. J Endocrinol. (2003) 178:29-36. doi: 10.1677/joe.0.1780029

113. Heasman SJ, Giles KM, Rossi AG, Allen JE, Haslett C, Dransfield I. Interferon gamma suppresses glucocorticoid augmentation of macrophage clearance of apoptotic cells. Eur J Immunol. (2004) 34:1752-61. doi: 10.1002/eji.200324698

114. Gratchev A, Kzhyshkowska J, Utikal J, Goerdt S. Interleukin-4 and dexamethasone counterregulate extracellular matrix remodelling and phagocytosis in type-2 macrophages. Scand J Immunol. (2005) 61:10-7. doi: 10.1111/j.0300-9475.2005.01524.x

115. Michlewska S, Dransfield I, Megson IL, Rossi AG. Macrophage phagocytosis of apoptotic neutrophils is critically regulated by the opposing actions of proinflammatory and anti-inflammatory agents: key role for TNF-alpha. Faseb J. (2009) 23:844-54. doi: 10.1096/fj.08-121228

116. Gerke V, Creutz CE, Moss SE. Annexins: linking Ca2+ signalling to membrane dynamics. Nat Rev Mol Cell Biol. (2005) 6:449-61. doi: $10.1038 / \mathrm{nrm} 1661$

117. Perretti M, D'Acquisto F. Annexin A1 and glucocorticoids as effectors of the resolution of inflammation. Nat Rev Immunol. (2009) 9:62-70. doi: $10.1038 /$ nri2470

118. Maderna P, Yona S, Perretti M, Godson C. Modulation of phagocytosis of apoptotic neutrophils by supernatant from dexamethasone-treated macrophages and annexin-derived peptide Ac(2-26). J Immunol. (2005) 174:3727-33. doi: 10.4049/jimmunol.174.6.3727

119. Schaer DJ, Boretti FS, Schoedon G, Schaffner A. Induction of the CD163-dependent haemoglobin uptake by macrophages as a novel anti-inflammatory action of glucocorticoids. Br J Haematol. (2002) 119:23943. doi: 10.1046/j.1365-2141.2002.03790.x

120. Shepherd VL, Konish MG, Stahl P. Dexamethasone increases expression of mannose receptors and decreases extracellular lysosomal enzyme accumulation in macrophages. J Biol Chem. (1985) 260:160-4.

121. Zahuczky G, Kristof E, Majai G, Fesus L. Differentiation and glucocorticoid regulated apopto-phagocytic gene expression patterns in human macrophages. Role of Mertk in enhanced phagocytosis. PLoS ONE. (2011) 6:e21349. doi: 10.1371/journal.pone.0021349

122. Garabuczi É, Sarang Z, Szondy Z. Glucocorticoids enhance prolonged clearance of apoptotic cells by upregulating liver $\mathrm{X}$ receptor, peroxisome proliferator-activated receptor- $\delta$ and UCP2. Biochim Biophys Acta. (2015) 1853:573-82. doi: 10.1016/j.bbamcr.2014.12.014

123. McColl A, Bournazos S, Franz S, Perretti M, Morgan BP, Haslett C, et al. glucocorticoids induce protein S-dependent phagocytosis of apoptotic neutrophils by human macrophages. J Immunol. (2009) 183:2167-75. doi: 10.4049/jimmunol.0803503

124. Seitz HM, Camenisch TD, Lemke G, Earp HS, Matsushima GK. Macrophages and dendritic cells use different Axl/Mertk/Tyro3 receptors in clearance of apoptotic cells. J Immunol. (2007) 178:5635-42. doi: 10.4049/jimmunol.178.9.5635

125. Dougherty TF, Schneebeli GL. Role of cortisone in regulation of inflammation. Proc Soc Exp Biol Med. (1950) 75:854-9. doi: 10.3181/00379727-75-18368

126. Gell PG, Hinde IT. The effect of cortisone on macrophage activity in mice. Br J Exp Pathol. (1953) 34:273-5.

127. Franchimont D, Martens H, Hagelstein MT, Louis E, Dewe W, Chrousos GP, et al. Tumor necrosis factor alpha decreases, and interleukin-10 increases, the sensitivity of human monocytes to dexamethasone: potential regulation of the glucocorticoid receptor. J Clin Endocrinol Metab. (1999) 84:2834-9. doi: $10.1210 /$ jcem.84.8.5931

128. Song E, Ouyang N, Hörbelt M, Antus B, Wang M, Exton MS. Influence of alternatively and classically activated macrophages on fibrogenic activities of human fibroblasts. Cell Immunol. (2000) 204:19-28. doi: 10.1006/cimm.2000.1687

129. Varga G, Ehrchen J, Tsianakas A, Tenbrock K, Rattenholl A, Seeliger S, et al. Glucocorticoids induce an activated, anti-inflammatory monocyte subset in mice that resembles myeloid-derived suppressor cells. J Leukoc Biol. (2008) 84:644-50. doi: 10.1189/jlb.1107768

130. van de Garde MD, Martinez FO, Melgert BN, Hylkema MN, Jonkers RE, Hamann J. Chronic exposure to glucocorticoids shapes gene expression and modulates innate and adaptive activation pathways in macrophages with distinct changes in leukocyte attraction. J Immunol. (2014) 192:1196-208. doi: 10.4049/jimmunol.1302138

131. Heideveld E, Hampton-O'Neil LA, Cross SJ, van Alphen FPJ, van den Biggelaar M, Toye AM, et al. Glucocorticoids induce differentiation of monocytes towards macrophages that share functional and phenotypical aspects with erythroblastic island macrophages. Haematologica. (2018) 103:395-405. doi: 10.3324/haematol.2017.179341

132. Pemmari A, Paukkeri E-L, Hämäläinen $M$, Leppänen $T$, Korhonen R, Moilanen E. MKP-1 promotes anti-inflammatory M(IL-4/IL-13) macrophage phenotype and mediates the anti-inflammatory effects of glucocorticoids. Basic Clin Pharmacol Toxicol. (2018) 124:404-15. doi: $10.1111 /$ bcpt.13163

133. Werb Z. Biochemical actions of glucocorticoids on macrophages in culture. Specific inhibition of elastase, collagenase, and plasminogen activator secretion and effects on other metabolic functions. J Exp Med. (1978) 147:1695-712. doi: 10.1084/jem.147.6.1695

134. Werb Z, Foley R, Munck A. Glucocorticoid receptors and glucocorticoidsensitive secretion of neutral proteinases in a macrophage line. J Immunol. (1978) 121:115-21.

135. Gratchev A, Guillot P, Hakiy N, Politz O, Orfanos CE, Schledzewski K, et al. Alternatively activated macrophages differentially express fibronectin and its splice variants and the extracellular matrix protein betaIG-H3. Scand J Immunol. (2001) 53:386-92. doi: 10.1046/j.1365-3083.2001.00885.x

136. Armbrust $\mathrm{T}$, Kreissig M, Tron K, Ramadori G. Modulation of fibronectin gene expression in inflammatory mononuclear phagocytes 
of rat liver after acute liver injury. J Hepatol. (2004) 40:638-45. doi: 10.1016/j.jhep.2003.12.013

137. Jubb AW, Boyle S, Hume DA, Bickmore WA. Glucocorticoid receptor binding induces rapid and prolonged large-scale chromatin decompaction at multiple target loci. Cell Rep. (2017) 21:3022-31. doi: 10.1016/j.celrep.2017.11.053

138. Oh K-S, Patel H, Gottschalk RA, Lee WS, Baek S, Fraser IDC, et al. Anti-inflammatory chromatinscape suggests alternative mechanisms of glucocorticoid receptor action. Immunity. (2017) 47:298-309.e295. doi: 10.1016/j.immuni.2017.07.012

139. Uhlenhaut NH, Barish GD, Yu RT, Downes M, Karunasiri M, Liddle C, et al. Insights into negative regulation by the glucocorticoid receptor from genome-wide profiling of inflammatory cistromes. Mol Cell. (2013) 49:15871. doi: 10.1016/j.molcel.2012.10.013

140. Chinenov Y, Gupte R, Dobrovolna J, Flammer JR, Liu B, Michelassi FE, et al. Role of transcriptional coregulator GRIP1 in the anti-inflammatory actions of glucocorticoids. Proc Natl Acad Sci USA. (2012) 109:11776-81. doi: 10.1073/pnas. 1206059109

141. Rollins DA, Kharlyngdoh JB, Coppo M, Tharmalingam B, Mimouna S, Guo Z, et al. Glucocorticoid-induced phosphorylation by CDK9 modulates the coactivator functions of transcriptional cofactor GRIP1 in macrophages. Nat Commun. (2017) 8:1739. doi: 10.1038/s41467-017-01569-2

142. D’Adamio F, Zollo O, Moraca R, Ayroldi E, Bruscoli S, Bartoli A, et al. A new dexamethasone-induced gene of the leucine zipper family protects $t$ lymphocytes from TCR/CD3-activated cell death. Immunity. (1997) 7:80312. doi: 10.1016/S1074-7613(00)80398-2

143. Berrebi D, Bruscoli S, Cohen N, Foussat A, Migliorati G, BouchetDelbos L, et al. Synthesis of glucocorticoid-induced leucine zipper. (GILZ) by macrophages: an anti-inflammatory and immunosuppressive mechanism shared by glucocorticoids and IL-10. Blood. (2003) 101:729-38. doi: 10.1182/blood-2002-02-0538
144. Shibata M, Katsuyama M, Onodera T, Ehama R, Hosoi J, Tagami H. Glucocorticoids enhance Toll-like receptor 2 expression in human keratinocytes stimulated with Propionibacterium acnes or proinflammatory cytokines. J Invest Dermatol. (2009) 129:375-82. doi: 10.1038/jid.20 08.237

145. Su Q, Pfalzgraff A, Weindl G. Cell type-specific regulatory effects of glucocorticoids on cutaneous TLR2 expression and signalling. $J$ Steroid Biochem Mol Biol. (2017) 171:201-8. doi: 10.1016/j.jsbmb.2017. 03.023

146. Yang YH, Aeberli D, Dacumos A, Xue JR, Morand EF. Annexin-1 regulates macrophage IL-6 and TNF via glucocorticoid-induced leucine zipper. $J$ Immunol. (2009) 183:1435-45. doi: 10.4049/jimmunol.0804000

147. Hoppstadter J, Kiemer AK. Glucocorticoid-induced leucine zipper. (GILZ) in immuno suppression: master regulator or bystander? Oncotarget. (2015) 6:38446-57. doi: 10.18632/oncotarget.6197

148. Jubb AW, Young RS, Hume DA, Bickmore WA. Enhancer turnover is associated with a divergent transcriptional response to glucocorticoid in mouse and human macrophages. J Immunol. (2016) 196:813-22. doi: $10.4049 /$ jimmunol.1502009

Conflict of Interest Statement: The authors declare that the research was conducted in the absence of any commercial or financial relationships that could be construed as a potential conflict of interest.

Copyright $\odot 2019$ Desgeorges, Caratti, Mounier, Tuckermann and Chazaud. This is an open-access article distributed under the terms of the Creative Commons Attribution License (CC BY). The use, distribution or reproduction in other forums is permitted, provided the original author(s) and the copyright owner(s) are credited and that the original publication in this journal is cited, in accordance with accepted academic practice. No use, distribution or reproduction is permitted which does not comply with these terms. 